Biografistyka Pedagogiczna

Rok 4 (2019) nr 1

ISSN 2543-6112; e-ISSN 2543-7399

DOI: 10.36578/BP.2019.04.21

Avital Hecht*

\title{
Women and Men in Argentinean Political Tradition (1810-1947)
}

Abstract: María Estela Martínez de Perón, better known as Isabel Perón, became president of Argentina upon her husband's death in 1974. She first served as vice president to her husband, Juan Domingo Perón, during his third term in office, starting in 1973.

Compared to Peron, Argentina's most legendary leader, serving from 1976 to 1974, Isabel (Peron's third wife) possessed no evident leadership skills. Isabel significantly differed from Peron's second wife, Eva (Evita) Perón, who was viewed as the sanctity in the eyes of its people. Eva served as a key partner in Peron's rise to power during his first term in 1951-1946, accompanying him through his election campaign in which he was elected to a second term. Peron was overthrown from office in 1955 in a military coup. His second term began with an attempt to present the candidacy of Eva for vice president which proved unsuccessful as military chiefs, original partners of Peron, failed to support Eva's candidacy.

Very few women have been key players in Argentinian history. Change came about, however, during Peron's first term, with support for women's suffrage in 1947. With popular support ensuring the leader's second term, this point in time changed the map on women's rights. So while not considered a saint, such as Eva, Isabel may be analyzed as part of the personal and political life of Peron, as well as a key figure in Argentinian history.

Key word: Eva (Evita) Perón, Juan Domingo Perón, political tradition.

* Avital Hecht - Head of Pre-Academic Studies and SHOA Memorial Center in Academic College of Education-Gordon, Haifa Israel, e-mail: hechtavital@gordon.ac.il. 


\section{Machismo and Marianismo}

Machismo and Marianismo are idioms used to characterize the relationship between genders in Latin American society. The Spanish colonial culture formed a society that presumably had no linkage to the local culture of Indian tribes but relied on the gender patterns the conquistadores brought with them. In fact, in the society that was created the male established his place based on the Macho figure, infusing its surrounding with a sense of pride and selfassurance, while the female was confined to the family's home, with inferior rights and dependent on the men around her. It seems that the gap between men's and women's rights and standing in Latin America is wider than in Spain itself. This can also be explained by considering the very low number of Spanish women in the new territories during the first period after taking it over and the fact that loose family systems were formed where a Spaniard was accompanied by a woman of Indian origin or mixed breed (Mestiza). ${ }^{1}$ In the social sense, Machismo and Marianismo still existed in Latin American territories after gaining independence. Later, despite the fact that women's political standing underwent changes during the twentieth century when they began to play a role outside of home, saying that women are seen as equal in the traditional 'manly theatre' was not an option .

Machismo originates from the Spanish word macho (man). This expression and concept demonstrates an array of approaches incorporated under an ideological conceptualization that attributes men supremacy over women in significant areas of life such as work, education, culture and politics. A Machismo strives to perpetuate a hierarchy in which the woman would always be subordinate to the man based on the man's role as patriarch. However, it is noteworthy that Machismo is also used to refer to relations between men, whereas Macho is one who is more militant, aiming to lead and a ladies' man.

Marianismo is a sociological term that is often presented as the opposite of Machismo. It is designed to highlight a woman's supremacy in her maternal and emotional roles. Based on the woman's allegedly unlimited capabil-

1 A woman of mixed ethnic ancestry; in Latin America this usually means a Spanish father and an Indian mother. 
ity to demonstrate chastity and a sense of self-sacrifice, Marianismo attributes spiritual and emotional superiority to women. This feminine stereotype is based on the woman's natural capacity as a 'mother' (as in the clear example of the Virgin Mary in the Catholic religious tradition). A woman is perceived as the queen of the house, capable of taking care of the whole family, while demonstrating superior strengths, whereas the man, according to the Machismo, is the one dominating the street, providing and protecting his household.

The roots of the Machismo in Argentinean society are a sound foundation of the society that evolved under Spanish colonialism, gladly embracing and nurturing many of its characteristics, as a basis for raising many generations. This type of culture grew in most Latin American countries and had an impact on them. Distinctive Macho characteristics can be detected in the cultures of countries such as Brazil, Mexico and Argentina; countries that were significantly influenced by social norms introduced by Portuguese and Spanish conquerors and colonists. Some might say that these Iberian countries absorbed a great deal from Arab culture and its hierarchical and patriarchal characteristics pursuant to the Moslem invasion and conquest of the Iberian Peninsula in the eighth century. By Arab tradition, the man's role in the family was based on his concern for the welfare and livelihood of the family unit. Furthermore, his authoritative position was enhanced by the permission Islam gives him to marry more than one woman.

Therefore, according to the macho concept, a man is characterized by a sense of pride, authority, power and aggression. David Sequeira defines Machismo as a mix of beliefs, approaches, values and behaviour that trickled down to the Hispanic family for many generations. ${ }^{2}$

Evelyn Stevens defines Machismo as a masculinity ritual, characterizing inter-personal relations with arrogance and uncompromising excessive aggression. Yet, she asserts that there are also positive characteristics of the Macho figure such as courage, loyalty, personal sense of pride, respect for others, leadership and responsibility towards those surrounding him (including his family and community). ${ }^{3}$

2 D. Seqeira, The Machismo and Marianismo Tango, Pittsburgh 2009, p. 8.

3 E. P. Stevens, 'Machismo and Marianismo', Society, Sept-Oct 1973, Vol. 10, No 6, pp. 59-60 
Apart from the ideological positions and attitude towards women and family, the Macho figure has stuck deep roots into the political level of Latin American society. There is a clear circumstantial connection between salient leadership characteristics and the Macho outlook that relies on demonstration of immense strength and a sense of pride. After Latin American countries declared independence, most their leaders embraced the Macho figure.

Throughout the nineteenth century, Caudillos ${ }^{4}$, or tyrants, took over most of these countries. Despite the development of democratic regimes in the twentieth century, the Macho leader image retained its dominance in Latin American politics. Prominent Latin American leaders of the nineteenth and twentieth centuries who assumed unmistakable Macho characteristics include Juan Manuel de Rosas ${ }^{5}$, Justo José de Urquiza ${ }^{6}$, Juan Domingo Perón and Carlos Ménem ${ }^{7}$ in Argentina and Hugo Chávez in Venezuela. ${ }^{8}$

According to Marcela Gaitan ${ }^{9}$, the Macho figure is an egocentric creature that takes violent measures to intimidate those around him. The Macho is admired for the physical and personal strengths that are manifested in all his deeds. Therefore, the Hispanic male, be that in the Iberian Peninsula or in the countries that are directly influenced by this culture, acts in a domineering way. He demands respect and submission and humiliates women in his method of communication, and demands approval of his actions from those

4 Caudillos - Political figure that took shape in the second decade of the nineteenth century. Its ruling method began right after Latin American countries gained independence. Refer to I. Rachum, 'Latin American Caudillos: The rise, advance and possible demise of a political tradition', in: Bar Ilan Studies in History v., Ramat Gan 2007, pp. 117-139.

5 Juan Manuel de Rosas was a Caudillo in the Buenos Aires area and later controlled vast regions in Argentina. He represented the agricultural aristocracy and ruled from 1835 to 1852 .

6 Justo Jose de Urquiza was a Caudillo and later also served as governor of Entre Rios. He fought alongside Rosas and later against him when he led a coalition of provinces, demanding to impose a federal system.

7 Juan Carlos Ménem was in office as the president of Argentina on behalf of the Peronist party between 1989 and 1999. His political roots can be found in La Rioja.

8 Hugo Chávez Served as president of Venezuela between 1999 and 2013.

9 M. Gaitán, The Terminology of Machismo, Trmpe, Arizona 1975, p. 9. 
around him. Anyone who disagrees with him, for this reason alone, is regarded as his personal enemy. Another characteristic attributed to the Machismo is a sense of pride. This is usually manifested in the man's dignified occupation and his ability to function within a peer society. Among other things, the Compadre status defines a relationship that is formed between two people under the pretext of sponsoring a son that is about to be born. Therefore, the Compadre (godfather) is obligated to show respect towards the child's family, help at times of need and offer care and protection to the child's family. The relationship that is formed is carried out on foundations of respect, appreciation and esteem, and is a mutual source of a sense of pride. ${ }^{10} \mathrm{~A}$ sense of pride is a characteristic that also has an impact on the attitude a man has towards his wife or life partner, especially when he suspects the woman is romantically unfaithful to him. In such cases his revenge may take a murderous nature. ${ }^{11}$ The Macho objects to his wife leaving home on her own and even uses physical and verbal abuse as retribution for inappropriate behaviour, although he usually demonstrates contained and incessant rage towards her. ${ }^{12}$ Just as the Machismo defines the dominance of the male figure over the female, it also infers a refusal to attribute women an independent personality, acknowledging no more than their important role in the running of the family. According to Spanish tradition, underlying the Machismo concept, the woman's social standing and rights are defined according to her role in the family - mother, wife or sister. ${ }^{13}$ The woman accepts and submits to the boundaries set by the man who controls her life, including confining her indoors or close to home. As such, the woman in a Macho society turns into an inferior being; the purpose of her existence is to better the life of the man to whom she is subordinate and to please him. ${ }^{14}$ When the Macho returns home from work, he expects the woman who has been waiting at home to take care of his well-being. This is in addition to her household chores and rearing children.

10 Teresa San Román y Aurora González Echeverría, Las relaciones de parentesco, Barcelona 1994, pp. 19-21.

11 D. Sequeira. The Machismo and Marianismo Tango, p. 14

12 E. P. Stevens, „Machismo and Marianismo", p. 58.

13 D. Sequeira, The Machismo and Marianismo Tango, pp. 4-5.

14 Ibidem, p. 10. 
According to Stevens ${ }^{15}$ research, men and women in Latin American society accept their role and the dynamics between them, leading each party to act according to the other's expectations. Women are not interested in altering the relationship that was formed as part of the Machismo-Marianismo dichotomy, even seemingly taking pleasure in the 'holy burden' imposed on them. They refrain from taking action that may change their status with the exception of their struggle for suffrage, which evolved very gradually. ${ }^{16}$

Clearly, the traditional image of the woman in Latin American society is related to the home, the family and the role of mother. This is an untainted image with high moral standards, while the man's image is related to the street, the outdoor space and the family honour. As the woman is accredited with religious and spiritual values, her image corresponds with that of the Virgin Mary, mother of Jesus, on whom the myth of feminine mental strength is based, including the glorification of the maternal image. ${ }^{17}$ The Marianismo manifests the belief that women are spiritually exalted and that spirituality imparts them with dominance in the familial and home spaces. This is the source of the possible effect the woman has on her husband's decisions and world view, thus enabling her to also influence his political opinions, which are expressed in public space, the man's playground. ${ }^{18}$ While attempting to present the balance of power between men and women in view of the Machismo-Marianismo formula, one might say that the sexual component of the woman's gender identity is nearly nullified and is directed to her being a mother and saint. On the other hand, the man's gender image is directly related to his exaggerated physical capabilities and sexual prowess.

In Peronist Argentina, the Machismo-Marianismo dichotomy was manifested during Perón's first term by the image of Eva Perón, (known as Evita) who was instrumental in amplifying the might of her husband's leadership. On the one hand, she identified with Peronism and the workers' struggles in Argentina. On the other hand, she established her own image of a concerning

15 E. P. Stevens, 'Machismo and Marianismo', pp. 57-58.

16 Ibidem, p. 57.

17 N. Fuller, 'Sujetos sexuados, modernidad y cultura en América Latina,' in: En Torno a la Polaridad Machismo - Marianismo, Hojas del Warmi No 4, Barcelona 1992, p. 243.

18 E. P. Stevens, 'Machismo and Marianismo', p. 61. 
woman who aids the revolutionary struggle when her husband, Juan Domingo Perón, was in danger. All this was expressed in October 1945 when Perón was imprisoned by the military. Evita was willing to risk her own life for him and personally initiated the recruitment of the heads of the workers' movement to rally for his release. Yet, Evita usually presented herself as a woman dependent on Perón, dedicating her mere being to the revered leader and his people. In a speech from 1947, during Perón's first term in office, she said '[...] The woman's holy purpose does not narrow down to providing the nation with children, but men to humanity, men in a chivalrous and substantial meaning ${ }^{\prime 19}$. In her book, My Mission in Life [La Razón de Mi Vida], Evita writes in the introduction: ' [...] I never was anything and still am nothing, but a humble woman, one sparrow in a flock of sparrows [...] and he [Perón] was and still is a mighty condor flying high among the peaks and close to God, who has descended to me and taught me to fly... So, my life and heart are not mine... All my thoughts and emotions belong to Perón... ${ }^{20}$ the essence of my secret lies in my decision to serve my people, my homeland and Perón... ${ }^{21}$

In the chapter that discusses a woman's deliberation between going out to work and staying home, Evita writes: '... At the house's doorstep, an entire nation ends and new rules and rights begin... the rules and rights of the man who is sometimes a husband and sometimes a dictator. And there is no one who can intervene at this point... We are not present in governments. Absent from parliaments. From international organizations. We can be found neither in the Vatican nor the Kremlin. And we are absent from the Imperialists' general staffs... We have no presence in any of the world's centers of power. Yet, we are always there to help at the deathbed and in the bitter hours. It seems that our destiny is not the essence of creation but sacrifice. It is only worthy that our symbol will be as the mother of Christ under the crucifix....22

Without doubt, Evita, the unmistakable image of a woman of the Peronist party, presented herself and the Peronist women as those who wish to be

19 Evita's speech before the party wives held on November 19, 1947. Eva Perón, Yo Evita: habla a las mujeres: patria, pueblo, recuperación, Buenos Aires 1987.

20 Introduction to Evita's book Eva Perón. La Razón de mi Vida, Buenos Aires 1952.

21 Ibidem, p. 150.

22 Ibidem, pp. 275-284. 
dependent and sacrifice themselves for their husbands, according to the Marianist concept. Two months before she died of cancer on May 7, 1952, the parliament awarded Evita the title of Spiritual Leader of the Nation [Jefa Espiritual de la Nación]. ${ }^{23}$ After her death, there were even many attempts to canonize her within the Catholic Church. Although these attempts failed, the people called her Saint Evita [Santa Evita]. Evita, who never became a mother herself, was portrayed as a feminine figure and mother of the people and the nation. This image was similar to the image of woman in the Argentinean patriarchal society. The motherly image was accompanied by Evita's image as the one who fought for women's political rights, an image that was intensified in 1947 when the women's suffrage law passed. ${ }^{24}$

\section{The man as a leader and ruler in Argentina: the caudillismo and his representatives}

The word Caudillo is derived from the Latin word caput (Head). ${ }^{25}$ The Caudillio image came to fill the void left by the king or viceroy (Virrey) at the conclusion of the transition into political independence that gathered momentum in the Spanish empire in America between 1810 and $1824 .{ }^{26}$ The Caudillo phenomenon manifests an attempt to control political power centres. Bold and charismatic men became leaders as a result of their initiative and personal traits and usually by their own power and without a legal framework to establish their authority.. This is a recurring phenomenon, reliant on personal strength and the capability to employ violence using civic and sometimes military elements to establish or perpetuate political dominance.

The well-known Argentinean historian, José Luis Romero, defined the Cadillo's rule as a 'de-facto rule' based on authoritarian policy focused on the ruler's

23 M. Navarro, Evita, Buenos Aires 1981, p. 297.

24 The women's suffrage law was legislated on September 23, 1947 and was included in the 1949 constitutional reform and entered effect in the general elections held on November 11, 1951.

25 P. Castro, 'El Caudillismo en América Latina, Ayer y Hoy', Política y Cultura (México), 2007, No. 27.

26 Dictatorship in Spanish America, ed. H. M. Hamill, New York 1965, pp. 5-6. 
power. ${ }^{27}$ At times, the rule of the Caudillo needs neither an established framework, nor succession: it is perceived as temporary and individual. In the absence of the notion of a central regime's authority, an established national-scale system or agreed ruling conventions, the Caudillismo and Caudillos evolved and struck root. At times, this phenomenon is evident in local characteristics such as separatism and factionalism.

From 1820, the Caudillos took roles as political figures in the new countries of Latin America, providing leadership to a given geographic region. Ilan Rachum asserts that with their leadership, the Caudillos addressed social and economic needs seen in times of crisis that in essence also manifest loss of identity and connection. ${ }^{28}$ Rachum analysed the Caudillo's image characteristics and found similar attributes to those of the local Indian tribal leading figure the Cacique. ${ }^{29}$ Both figures have similar personality traits: valour, boldness, wisdom and elaborate rhetoric capabilities. The two figures strived to gain personal power that would lead to centralizing their rule and for this end, they had no reservations when it came to using force, weapons and political opportunism to overcome their opponents. Unlike the Cacique, the Caudillo is characterized by a greater level of urban elements even though the phenomenon originated in rural areas where estate owners felt an ever-growing insecurity due to the removal of Spanish authority representatives. Later, this led to collaborations and alliances between social strata that never worked together beforeCriollos and Mestizos. ${ }^{30}$ At times, with the absence of any other authority, the Caudillismo turned into a political system with several controlling groups that set the regional authority procedures in Argentina that operated concurrently and struggled among themselves. ${ }^{31}$ The estate owners hired the services

27 J.L Romero, A History of Argentine Political Thought, California 1963, pp. 110-111.

28 I. Rachum, in 'Leadership in Times of Crisis,' in: Bar Ilan Studies V, Ramat Gan 2011, pp. 119-139.

29 Ibidem, pp. 123-124

30 E. Wolf, and E. Hansen, 'Caudillo Politics: A Structural Analysis', Comparative Studies in Society and History 9 (1967) pp. 168-179.

31 '...In spite of chaotic appearance, Caudillaje was a true political system and organizes effort on the part of competing groups to determinate who got what, when and where...' in: ibidem, p. 69. 
of Gauchos, hair-trigger cowboys that formed militias, to keep their estates and property safe from bandits and other militia owners.

Based on highly masculine characteristics (Hombre Macho) ${ }^{32}$ defined by the renounced intellectual and writer, Domingo F. Sarmiento (later elected as Argentinean president from 1868 to 1874), the local Gauchos, whom he referred to in his book Facundo o Civilización y Barbarie en las Pampas Argentinas as Kings of Spurs ${ }^{33}$, turned into Caudillos, using uncompromising aggressiveness, killing and pillaging. This definition one can identify a combination of borderland in Argentina, use of horses and belligerent cowboys, leadership and physical prowess. During the effort to manifest leadership, Caudillos added military patterns to their regime. This was based on their own military backgrounds or came from their own his macho characteristics. So, it is evident that some Caudillos decided to embrace military characteristics such as ranks, uniforms and hierarchy. The cult of personality constituted part of the formation of Caudillos' personal prowess, which also included setting up statues commemorating heroism, armed and clad in uniform.

Now is the time to discuss the legitimacy of the Caudillo, while attempting to differentiate him from the image of Dictator. When executing political authority, legitimacy is a major component in the capability to acquire the citizens' trust. The Caudillo is not just a dictator that imposes himself on the people, but a leader who establishes his rule using charisma and rich rhetoric. Usually, his rule is characterized by patronage, providing subjects with a sense of security, and feeds this cult of personality. So, where a Caudillo rules, we can see the continuity (Continuismo) that Castro explained as a relatively protracted reign, during which democratic institutes have a tendency to be abolished, while new ones are established to perpetuate the Caudillo's rule. ${ }^{34} \mathrm{He}$ usually vacates his seat upon death or following an act of violence intended to depose him.

Sustaining the Caudillo's rule requires substantial financial resources. He is required to maintain his soldiers and provide economic security to his support-

32 Chevalier, 33: 'The Roots of Caudillismo', in: Caudillos: Dictators in Spanish America, ed. H. Hamill, New York 1965, p. 31.

33 Reyes de las Espuelas.

34 . P. Castro, 'El Caudillismo en América Latina, Ayer y Hoy', Política y Cultura, 27 (2007) p. 5 . 
ers. Therefore, Caudillos often used their powers to carry out property crimes against those that did not accept his authority. They placed their kin, friends and supporters in government offices, thus providing their supporters with secure livelihoods, while securing their own grip on the seat of power. Castro claims that Caudillos have no distinction between the public space of ruling and the private one, not even in the areas of property and its ownership. This attitude helped some of them accumulate considerable wealth and economic assets $^{35}$, which is also true in the case of Perón and his second wife, Evita.

In Sarmiento's analysis of the rural society in Argentina where the Caudillo stemmed from, there are four main figures that stand out: the tracker (rastreador), the cowboy (baqueano), the bad gaucho (gaucho malo) and the songster (cantor). Sarmiento presents the Caudillo figure as one that evolved from a gaucho into a gaucho malo and then into a gang leader, a battalion commander and eventually into the land-conquering general and all-mighty ruler of the land. ${ }^{36}$

We should remember that the meaning of the term Caudillo in Spanish language and culture is not unequivocally negative. For instance, the Spanish dictator Francisco Franco who ruled Spain from his victory in the Spanish Civil War (1936-1939) until his death on November 20, 1975, assumed the title Caudillo. During his rule, the coins minted by the Spanish treasury bore the title that manifested his own personal perception of his rule:Ruler of Spain in grace of God [Caudillo de España por la Gracia de Dios]. ${ }^{37}$

Towards the turn of the nineteenth century, the Caudillos did not vanish from the Latin American political arena. They became educated Caudillos (Caudillos Letrados) ${ }^{38}$ who paid attention to development of the countries' physical and social infrastructures, took care of local economies and invested in education as a leverage point for progress. The process of rulership and state establishment was formed and the daunting image of the Caudillos who ruled in the nineteenth century faded away. At the beginning of the twentieth century, the first president in Argentina elected by general and secret elections, realizing exclusively male suffrage, was Hipólito Yrigoyen (1916-1922, 1928-

35 Ibidem.

36 D. F. Sarmiento, Facundo, Santiago de Chile 1851, pp. 137-139.

37 I. Rachum, in: 'Leadership in Times of Crisis', p. 123.

38 Ibidem, p. 135. 
1930), a descendent of a large and politically influential family who were partfounders of the Radical Party. However, despite the democratic order that led him to the presidency, Yrigoyen often reverted to using Caudillo-type behaviour patterns.

The heyday of the Fascist parties in some European countries in the 1930s, based on physical might and personality cult, restored the prestige of the rulerCaudillo model to Latin America: Alfredo Stroessner in Paraguay (1954-1989), Anastasio Somoza and sons in Nicaragua (1936-1979), Getulio Vargas in Brazil and Juan Perón in Argentina (1946-1955).

\section{Noticeable women in Argentina's first hundred years of independence}

The development of political consciousness of women in Argentina was slow and delayed. During the country's first years of independence, only a few women stood out of the elite with their social and political activity. In some way, this resembled processes that took place in European capitals such as Paris and London in the second half of the eighteenth century. Later, throughout most of the nineteenth century, women of the upper classes were politically involved in reduced and discreet aspects, modestly and sparingly. Only at the turn of that century and the beginning of the twentieth century, did we witness a re-emergence of the trend of women getting involved in nationalscale politics and as before, this was also inspired Europe. This time, this was a much wider trend that encompassed middle-class women and bore a feminist agenda. Women who received European education, either of immigrant families or of well-established local families, began protesting and demanding women's rights on their return, both on a political level and on issues pertaining to working women's needs.

Since the beginning of the nineteenth century, especially after the declaration of independence in Argentina on July 9, 1816, there were women who managed to be the hub of substantial political activity. The first of them was Mariquita Sánchez de Thompson (1786-1868) ${ }^{39}$, a woman from the upper classes.

39 F. Pigna, Mujeres tenían que ser, Buenos Aires 2011, pp. 25, 34, 90. 
As the country got ready for the declaration of independence, her Buenos Aires home turned into an arena for political debates, and she gathered many of the contemporary public opinion leaders around her. In 1813, the national anthem that was composed just a year earlier was played for the first time in her house. She was very close to Bernardino Rivadavia who served as president from 1824 to $1825 .{ }^{40}$ Mariquita Sánchez de Thompson was also very active on a political level. She expressed her opinions on political events and later had a very close relationship with the Caudillio Juan Manuel de Rosas. Her personal life was also influenced by her uncompromising character; she continuously and fiercely fought with her parents who refused to allow her to marry her cousin, Martín Thompson, because they deemed his military career unfit for their family's social status. Eventually, in 1804, she sent her petition to the Spanish viceroy Sobremonte who oversaw the Río de la Plata region to approve her marriage. ${ }^{41}$ She held very liberal and progressive opinions for her time. In her numerous letters, one gets an impression of her progressive position on women's status in society and her position within marriage. ${ }^{42}$

There is another main female figure; Encarnación Ezcurra (1795-1838), wife of the ruthless Caudillo Juan Manuel de Rosas. Encarnación stood out in her political activism to turn Argentina in a federal country, supporting her husband who waved the same banner in the battlefield. For her persistence, she was referred to as Heroina de la Santa Federación. Their daughter, Manuelita de Rosas (1817-1898), was born into an independent Argentina and her parents built her character accordingly. At a young age she took her mother's place and accompanied her father on his political duties as governor of Buenos Aires. She followed her mother's exceptional political involvement.

Juana Gorriti, the well-known writer from Salta province, also an aristocrat, was a leading intellectual figure, both in her province and in the Cordoba prov-

40 S. Vallejos, 'Recuperando a Mariquita,' Página 12, Buenos Aires, 20.02.2008.

41 At the time, a woman of 25 years of age or less was required to receive her parents' approval to get married. Should the parents refuse and the young woman insist, in order to bypass her parents' decision, she had the right to appeal to the legal system to present her arguments for the marriage.

42 M. G. Mizraje, Intimidad y Política: diario, cartas y recuerdos de Mariquita Sánchez de Thompson, Buenos Aires 2003. 
ince. She was born in 1816 to a father who was the province governor. Later she lived in Bolivia and Peru and became a revered figure there as well as a role model for young female writers. ${ }^{43}$

Towards the end of the of the nineteenth century, European immigrants with progressive social attitudes began arriving at Argentinean shores. These immigrants brought up issues regarding the country's oligarchic regime at the time. In addition, women's rights became part of the new social debate, especially in view of the legislation stating that a man was head of the family and the lawful and formal representative of the women in his family ${ }^{44}$ in any civic context. At the time, Argentinean society reduced women's status to the image that they were esssentially confined to home and the family, according to the Marianismo principles.

In such a reality, at the beginning of the twentieth century, a line of women evolved in Argentina who stood out with their activity for promotion of women's status in society and demanded equal rights between the sexes, including women's suffrage. These women were deeply influenced by the political developments in Europe and the views spread by the old-world Socialist parties as well as by the messages the local Socialist party spread in Argentina. Some of them were second generation European immigrants. These women left for Europe to study at a young age and returned to Argentina to begin their adult life.

Italian Argentinean physician, Julieta Lanteri, born to Italian immigrants and one of the first women to study medicine in Argentina, founded the International Congress of Free Thought in 1906. Four years later she organized an international congress of women and even put herself up for elections for the national congress several times. The General Elections Law (Ley General de Elecciones), legislated by president Roque Saénz Peña on November 1O, 1912, stated that only menaged 18 and over, who were born in Argentina or with Argentinean citizenship were eligible to vote in general elections. In addition, it was stipulated that any person who had served in the army may vote. Therefore, Lanteri volunteered for army service in order to be able to vote. However, she was rejected and failed to join the army so could not obtain the muchdesired right to vote. Later, Lanteri and another physician, Alicia Moreau de

43 F. Pigna, Mujeres tenían que ser, pp. 56-57.

44 Refer to the paragraph No. 57 of the civil code (Código Civil) of 1869. 
Justo (1885-1986), arranged a simulation of general elections in which only women could participate. There 'elections' were held in the middle of a Buenos Aires street, expressing the women's protest against the denial of their basic civil rights. Four thousand women took part in this simulation, expressing their identification with the struggle. Lanteri continued to fight and in 1932 she supported the bill for women's suffrage.

Dr Alicia Moreau de Justo was married to Juan B. Justo, also a physician, who founded the Socialist party in Argentina in 1896. He headed the party until his death in 1926 and also served in several positions including member of congress and senator. Both practiced medicine and were highly involved in work for the poor. They also promoted implementation of pluralistic and socialist political views. Alicia was one of the leading figures in women's struggle for rights in Argentina. At a younger age, following a persistent struggle against academic establishment, she was one of the first six women to be admitted for medical studies in a Buenos Aires university. In fact, it was female physicians that raised the standard for women's rights, indicating to their higher development of political consciousness than other Argentinean women. It seems that the only framework that was open to accept Alicia's activism was the Socialist party that drew from ideological sources located in Europe where similar parties flourished at the beginning of the twentieth century.

The Chertkoff sisters, Fania, Mariana and Adela, Jewish immigrants from Odessa in the Ukraine, who settled in the Jewish community, Colonia Clara, in Ríos Entre, ${ }^{45}$ also has socialist and militant feminist views. They promoted the effort to establish educational systems for toddlers to allow mother to work.

There were other women who stood out in their activity in the second half of the nineteenth century. Cecilia Grierson (1859-1934), the first woman to graduate academic studies in Argentina, attended the first International Congress of Women that took place in London, England in 1899. Another physician worth mentioning is Elvira Rawson (1867-1954) who waged numerous struggles for equality between men and women and even co-founded (with the poet Alfonsina Storni) a women's rights organization with eleven thousand members. Other female intellectuals such as the authoress Eduarda Mansilla de García

45 One of the agricultural colonies founded by the Baron Hirsh in Santa Fé and Ríos Entre provinces. 
and the renounced sculptress Dolores Mora Vega, professionally known as Lola Mora, harnessed themselves to extensive political activity and demanded equal political rights for women and men in Argentina.

\section{The struggle for women's political rights during the first half of the twentieth century}

During the first half of the twentieth century, the major political parties in Argentina waged a heated debate on varied feminist issues. These developments were accompanied by political debates and even proposed legislation that expressed the parties' disposition on the matter of women's political rights. Indeed, women were granted suffrage during President Perón's first term in office in $1947^{46}$, however it would be hard to indicate to some continuum, ideological or practical, leading from the struggle waged by Socialist women and President Perón's resolution.

During the first decade of the twentieth century, both the Argentinean Socialist Party (Partido Socialista Argentino - PSA) and the smaller Liberal Party promoted the struggle for women's political rights. The large opposition middle-class party (Unión Civica Radical - UCR) did not host an organized feminist activity at the time and mainly focused on leading women who stood out by character or deed such as Eufrasia Cabral and Elvira Rawson. ${ }^{47}$ The latter, already mentioned above, organized a women's right organization, Pro Derechos de la Mujer, addressing all political parties. On the other hand, the feminist activity in the Socialist party, the PSA, was far more coordinated and established. As early as 1902, the women's socialist centre, Centro Socialista Femenino, was founded as part of the PSA. ${ }^{48}$ In 1918, Dr Lanteri founded a new party with a feminist platform, Partido Feminista Nacional.

The researcher Adriana Valobra mentions three formative events that constitute a breakthrough in women's struggle to obtain political rights in Argentina at the beginning of the twentieth century:

46 Women's suffrage was legislated on September 9, 1947.

47 D. Barrancos. Inclusión / Exclusión. Historia con Mujeres, Buenos Aires 2001, pp. 25-27.

48 D. Barrancos, 'Socialismo y sufragio femenino. Notas para la Historia 1890-1947,' in: El Partido Socialista en Argentina, ed. H. Camarero, C. Herrera, Buenos Aires 2005. 
A. The First International Women's Congress was held by the Academic Women's Organization in Buenos Aires in May 1910. Two hundred women from Europe, the Us and other Latin American countries, including Argentina participated.

B. Julieta Lanteri, with the help of the judicial system, managed to prove that the naturalization certificate she received from the state allowed her to exercise her civic rights, including voting. Her claim was based the country's constitution: it stated that activities not explicitly prohibited were permitted, and as the naturalization certificate did not mention a restriction of women's suffrage, it was therefore permitted. Dr Julieta Lanteri won her appeal against the state and in November 1911, she exercised her right to vote in the Buenos Aires municipal elections.

C. Women of San Juan in the San Juan province exercised their right to vote in local elections on two distinctive occasions in 1856 and 1862.

From 1918 until the 1940s, we also witnessed organized women's activities in Argentina within right-wing groups affiliated with the Catholic Church and social elites. The Argentinean Patriotic League (Liga Patriotica Argentina), a nationalistic and xenophobic organization, was formed in 1919 to fight the influence of the Bolshevik revolution. Members of the organization also took violent measures against politically and socially leftist organizations that stemmed from Europe and influenced the political views of mostly Jewish immigrants. Women also participated in the League's violent activities, and joined Catholic right-wing organizations where they were mainly involved in community initiatives dealing with educating and training the weaker parts of society. These women acted for the benefit of low-class children and women, following the nationalist and Catholic views that adhered to traditional family values alongside the efforts to expand literacy in this population, and especially among women. ${ }^{49}$ The Patriotic League also operated by way of guerrilla groups, from police stations where they also obtained their firearms. The League's members were responsible for the violent events that took place during the Tragic Week (Semana Trágica) in 1919, during which many immigrants, mostly Jews, who were suspected as having Communist, Anarchist and Marxist affiliation, were attacked and murdered.

49 M. Moscatelli, 'La Liga Patriótica Argentina. Una propuesta nacionalista frente a la conflictividad social en la década de 1920,' La Trama de la Comunicación, 7 (2007). 
When the Semana Trágica events were over, Rogelio Araya, a UCR member of congress, presented a bill to promote women's suffrage, an initiative of the Women's Rights Association. ${ }^{50}$ Since the beginning of the twentieth century, the UCR's ambivalent approach towards women's suffrage is evident. Although the party produced several bills on the subject, similar to the bill proposed by congressman Araya, none passed legislation. On the one hand, the Radical Party supported maternal feminism ${ }^{51}$, presenting the woman as the image of a mother. On the other hand, party leaders worried that potential constituents would see them as supporters of revolutionary and radical political changes such as modern, liberated women without obligations, hence leading to loss of their support.

In 1919, a group of intellectuals convened in Buenos Aires to express its opinion on the issue of forming feminism in Argentina. The discussions and resulting views were later published by Miguel Font in his book The Woman: a Feminist Survey of Argentina (La mujer encuesta feminista Argentina). ${ }^{52}$ Following analysis of the survey's findings, Font determined that the aspirations of feminism in Argentina were based on three components:

A. Granting women political rights, including the right to vote in any election, either local or national. Legitimizing women's political involvement as an expression of maternal sentiment based on their central role in raising and rearing of children.

B. Granting civic rights such as in the labour market. At the time, it became apparent that women's share in the Argentinean labour market neared thirty percent. An analysis of the survey findings revealed that working women were concerned by lack of rights in anything pertaining to their status regarding natural feminine issues such as childbirth.

C. Strengthening women's status morally, intellectually and economically. One of the topics that most survey participants found relevant was

50 E. R. Gallo, Las Mujeres en el Radicalismo Argentino 1890-1991, Buenos Aires 2001, pp. 60-62.

51 S. Palermo, 'Quiera el hombre votar, quiera la mujer votar: género y ciudadania política en Argentina (1912-1947),' in: El Sufragio Femenino en América Latina ${ }_{2}$ comp.

C. Barry, Buenos Aires 2006.

52 M. Font, La Mujer: Encuesta Feminista Argentina, Buenos Aires 1921. 
the demand for economic independence and self-management of women's property. In the civil code (Código Civil) of 1869 it was determined that a woman's assets and income should be managed by her husband if married or by her father if not. In addition, the subject of divorce came up as a woman's basic right to freely elect to terminate her mutual life with her husband. ${ }^{53}$

Towards the 1930s, growing support for granting women with political rights could be detected in many political parties and social organizations. Organizations affiliated with the Catholic Church also fostered groups that supported granting suffrage according to the person's education, omitting gender from the criteria. This meant that educated women and men, as defined by the law, would be allowed to vote, while other, uneducated, citizens, men and women alike, would be denied this right. ${ }^{54}$ In 1929, a member of the lower house of representatives, José Bustillo, hijo submitted a bill on behalf of the UCR demanding suffrage for literate women as long as they voluntarily registered in the poll book. ${ }^{55}$ Unlike the UCR, the Socialist party asserted that men and women were equal, thus their rights were equal. As of the late 1920s, party representatives lead the demand to grant women voting rights. ${ }^{56}$ The Socialist senator Mario Bravo's bill was the only one to reflect a desire for absolute electoral equality between men and women, following the socialist paradigm. ${ }^{57}$ In 1932 , a parliamentary committee was established and submitted its recommendations. These were discussed and approved in the lower house of representatives and transferred to the Senate, where they never got to the stage of being voted upon. At the same time, the Conservatives in the lower house took their position against women's suffrage to extremes and claimed that women lacked the character for politics, since women's traits and emotional devotion required

53 M. Nari, 'Feminismo y diferencia sexual. Analisis de la «Encuesta Feminista Argentina» de 1919,' Boletín de historia Argentina y Americana Dr. Emilio Ravignani, Tercera serie, No. 12 , 2 semester 1995.

54 In 1933, Carmela Burmeister brought up the proposition as part of her activity in the Asociación Argentina de Sufragio Femenino. Refer to Valobra. Ibidem,_p. 13.

55 CNDSCD, 11/9/1929, p. 315 (bill filed in the library of the lower house of Congress in Argentina).

56 D. Barrancos. Inclusión / Exclusión, pp. 159-180.

57 CN, Camara de Diputados, Diario de Sesiones 11-25 octubre 1929, pp. 325-341. 
active and constant protection by men. A member of the lower house, Francisco Uriburu, even claimed that '... allowing equalization of women's rights to those of men would lead to the dissolution of the institute of the family by infection with Anarchy bacteria.... ${ }^{58}$

Thing took an interesting turn in 1934 in the San Juan province, where for the first time in South America, a woman, Emar Acosta, was elected to the province's house of representatives as a representative of the National Democratic Party. It should be emphasized that at the time, the local government was acting under supervision and involvement of the conservative central administration. In 1928, the women of San Juan voted in the local elections. The provincial house of representatives ratified this law as early as 1917. Despite its relative richness and higher level of education, Argentina lagged behind neighbouring Brazil, where the October 1930 revolution carried liberal ideas and enabled president Getulio Vargas to approve women's suffrage by presidential decree two years later.

In 1941, a women's front, the Union of Victory (La Junta de la Victoria) ${ }^{59}$ was formed in Argentina. This brought women from various parties and religions together with a joint cause - to promote achievement of political and democratic rights for women and to battle the Fascist trends that arrived from Europe. The organization had 125 chapters all over Argentina and at the beginning of 1943 it organized a demonstration of 45,000 woman ${ }^{60}$ who demanded democratic rights for women, including suffrage. At the time, most parties included active women, yet, apart from the very marginal Communist party, there was no apparent increase in the number of women serving in party institutes. The Military government established after the deposing of President Ramón Castillo on July 4, 1943 banned the organization from operation and shut it down. In 1946, only a year prior to the legislation that granted women's suffrage during Perón's first term in office, the bill to grant women with the right to vote was included in the Radical Party's (UCR) platform.

58 CN, DSCD 15/9/1932, p. 47.

59 D. Barrancos, Mujeres en la sociedad argentina. Una historia de cinco siglos, Buenos Aires 2012, pp. 154-156.

60 A. M. Valobra, 'Feminismo, sufragismo y mujeres en los partidos politicos en la Argentina de la primera mitad del siglo XX', Amnis, 8 (2008), pp. 15-16. 
The researcher Barrancos refers to women's public activity in Argentina as Feminine Enterprises (Agencias Femeninas) ${ }^{61}$ for society to promote their ideological agenda. It is possible to see a considerable match between women's political activity for their rights and their adherence to left-wing ideological views. Most activity was related to the Socialist party and women's associations in industries with affinity to movement of the left side of the political map or affiliated organizations. Despite the liberal influences that gradually entered the Argentinean society in political and social life, due to the influence of the Catholic Church, this was not the case when it came to women in Argentina. ${ }^{62}$

\section{Conclusions}

The greater part of public activity by women in Argentina during the nineteenth and twentieth centuries was typified by helping the mother and community, and gradually expanded to active political realms. During the nineteenth century, most of the active woman that were part of frameworks dwelling alongside the political system were of the higher classes. Apart from activists with a socialist ideology that in some way tied them to European roots, active women were operating from within an aristocratic or oligarchic social shell. It should emphasized that the consciousness of partaking in political life that crystallized in Argentinean women did not manage to enter the civic level and generate a substantial change in the Macho and Paternalist state of mind prevalent in Argentinean society. Parties that supported women's struggle to gain electoral rights did not help promote women's aspirations. They failed to change the attitude of the vast majority of party members and leaders with regards to women's overall social status, and in general, acted in a hesitant and non-resolute manner every time promotion of women's rights was on the agenda. Even Perón's personal and exclusive decision to allow women's suffrage in 1947 was an exceptional and surprising move. This decision originated from a precise

61 D. Barrancos, 'Las Mujeres y su Causa', in: Sociedad, Sept. 2005, No. 2308.

62 D. Barrancos, „Problematic Modernity: Gender, Sexuality and Reproduction in Twentieth-Century Argentina", Journal of Women's History, 18 (2006), No. 2, pp. 123-150. 
and personal political consideration and was not part of a civic consciousness aspiring to integrate women in society based on their natural rights.

Although they made a few significant accomplishments, women in Argentina were excluded from all aspects of civil integration throughout almost the entire century. On November 6, 1991 law No. 24.012 passed, determining that every party should present a list of candidates to congressional elections of at least thirty percent women. In 1994, this law became article 37 of the constitution, thus securing women's position in the political system. This turned Argentina into the leading country in Latin America in the relative number of female members of parliament. ${ }^{63}$ This integration into key positions and the need to maintain a quota set in law led to a substantial change and gave women equal rights and opportunities in a society that predominantly remained based on Macho and Paternalism.

Streszczenie: María Estela Martínez de Perón, znana jako Isabel Perón, została prezydentem Argentyny po śmierci męża w 1974 r. Po raz pierwszy pełniła funkcję wiceprezydenta męża, Juana Domingo Peróna, podczas jego trzeciej kadencji, od 1973 r.

W porównaniu z Peronem, najbardziej legendarnym przywódcą Argentyny, rządzącym w latach 1976-1974, Isabel (trzecia żona Perona) nie posiadała widocznych umiejętności przywódczych. Isabel znacznie różniła się od drugiej żony Perona, Evy (Evita) Perón, którą postrzegano jako „świętość” w oczach mieszkańców kraju. Ewa była partnerem Perona podczas dochodzenia do władzy przed pierwszą kadencją w latach 19511946, towarzyszyła mu podczas kampanii wyborczej, w której został wybrany na drugą kadencję. Peron został obalony z urzędu w 1955 r. w wyniku wojskowego zamachu stanu. Jego druga kadencja rozpoczęła się od próby przedstawienia kandydatury Ewy na wiceprezydenta, zabieg okazał się nieskuteczny, ponieważ dowódcy wojskowi, pierwotni partnerzy Perona, nie poparli kandydatury Ewy.

Bardzo niewiele kobiet odgrywało kluczową rolę w historii Argentyny. Zmiana nastąpiła jednak podczas pierwszej kadencji Perona, który popar zdobycie praw wyborczych przez kobiety w 1947 r. Chociaż Isabel nie jest uważana za świętą, taką jak Ewa, jej postać może być analizowana jako osoba towarzysząca Peronowi w życiu osobistym i politycznym, a także jako kluczowa postać w historii Argentyny.

Słowo kluczowe: Isabel Perón, Eva (Evita) Perón, Juan Domingo Perón, tradycja polityczna.

63 E. M. Carrio, M. Méndez-Montalvo, J. Ballington, 'Los retos de la participación de las mujeres en el Parlamento. Una nueva mirada al caso argentino,' Mujeres en el Parlamento. Más allá de los números, 2002, pp. 135-146. 


\section{Bibliography}

Perón E., Mensajes y Discursos, Buenos Aires 1999.

Perón E., Yo Evita: habla a las mujeres: patria, pueblo, recuperación, Buenos Aires 1987.

Barrancos D., Inclusión / Exclusión. Historia con mujeres. Buenos Aires 2001.

Barrancos D., Mujeres en la sociedad argentina. Una historia de cinco siglos, Buenos Aires 2012.

Font M., La Mujer: Encuesta Feminista Argentina, Buenos Aires 1921.

Gaitán M., The terminology of machismo, Chicago 1975.

Dictatorship in Spanish America, ed. H. Hamill, New York 1965.

Mizraje M. G., Intimidad y Política: diario, cartas, y recuerdos de Mariquita Sánchez de Thompson, Buenos Aires 2003.

Navarro M., Evita, Buenos Aires 1981.

Pigna F., Mujeres tenían que ser, Buenos Aires 2011.

Seqeira D., The Machismo and Marianismo Tango, Pittsburgh 2009.

Barrancos D., 'Las mujeres y su causa,' Sociedad, 2005, No 2308.

Barrancos D., 'Socialismo y sufragio femenino. Notas para la historia 1890-1947', in: El Partido Socialista en Argentina, H. Camarero, \& C. Herrera, Buenos Aires 2005.

Barrancos D., 'Problematic Modernity: Gender, Sexuality and Reproduction in Twentieth-Century Argentina,' Journal of Women's History, 18 (2006), No. 2, pp. 123-150.

Castro P., 'El Caudillismo en América Latina, Ayer y Hoy,' Política y Cultura, 27 (2007), pp. 2-31.

Carrio E. M., M. Méndez-Montalvo, and J. Ballington, 'Los retos de la participación de las mujeres en la Parlamento. Una nueva mirada al caso argentino,' in: Mujeres en el Parlamento. Más allá de los números, 2002, pp. 135-146.

Chevalier F., 'The Roots of Caudillismo,' in: Caudillos: Dictators in Spanish America, ed. H. Hamill, New York 1965.

Fuller N., 'Sujetos sexuados, modernidad y cultura en América Latina,' in: En Torno a la Polaridad Machismo-Marianismo. Hojas del Warmi, 1992, No 4, pp. 54-68.

Moscatelli M., 'La Liga Patriótica Argentina. Una propuesta nacionalista frente a la conflictibilidad social de la década de 1920', La trama de la comunicación, 2007, No 7.

Nari M., 'Feminismo y diferencia sexual. Análisis de la "Encuesta Feminista Argentina" de 1919,' Boletín de historia argentina y Americana - Dr. Emilio Ravignani. Tercera serie, 1995 , No 12.

Navarro M., 'Evita, el Peronismo y el Feminismo', in: Racionalidad en el Peronismo, eds. J. E. Miguens y F. C. Turner, Buenos Aires 1988, p. 117-166.

Palermo S., 'Quiera el hombre votar, quiera la mujer votar: género y ciudadanía política en Argentina (1912-1947),' in: El Sufragio Femenino en América Latina, comp. C. Barry, Buenos Aires 2006, pp. 1-68.

Pigna F., La Liga Patriótca Asesina, www.elhistoriador.com.ar. 
Rachum I., 'Leadership in times of crisis,' in: Bar Ilan Studies in History, Ramat Gan 2011, pp. 117-139.

Schein V., 'Sex roles stereotypes and requisite management characteristics past present and future,' in: National Center of Management Research and Development, London 1989, pp. 151-154.

Scott J. W., 'Gender: A Useful Category of Historical Analysis,' American Historical Review, 1986, No 91 (5), pp. 1053-1075.

Stevens E. P., 'Machismo and Marianismo,' Society, 197310 (6), pp. 57-71.

Vallejos S., 'Recuperando a Mariquita,' Página, 200812, 20.2.2008.

Valobra A. M., 'Feminismo, sufragismo y mujeres en los partidos politicos en la Argentina de la primera mitad del siglo XX', Amnis, 2008, No 8, pp. 12-39. 